\title{
FEDERAL ALMAN DIŞISŞLERİ ARŞIV BELGELERINE GÖRE DEMOKRAT PARTI DÖNEMI TÜRK-ALMAN ILIŞKILERINDE 1957 SEÇIM SÜRECI
}

\author{
1957 Elections Process in Turkish-German Relations during Democratic Party Era \\ According to the German Federal Foreign Office Archive Documents
}

\section{Gökhan EŞEL}

Anahtar Kelimeler: Demokrat Parti, Türk-Alman İlişkileri, 1957 Seçimleri

JEL Kodları: F5, N4, Z0

Keywords: Democratic Party, Turkish-German Relations, 1957 Elections

JEL Codes: F5, N4, Z0

\section{Özet}

Türk-Alman ilişkileri, başlangıcından itibaren ticari ve askeri müttefiklik ekseninde süregelmiş ve her iki devlet açısından da bakıldığında ilişkilerin güçlendirilmesine ve geliştirilmesine büyük önem verilmiştir. Nitekim, Türk diş politikasında önemli olayların yaşandığı Demokrat Parti İktidarı döneminde, batı ile ilişkilerin gelişmeye başlaması Türkiye'nin NATO'ya üye olmasını da beraberinde getirmişti. Bu süreçte II. Dünya Savaşı sonrasında Doğu ve Batı'ya ayrılan Almanya'nın batı tarafı, yani Federal Almanya Devleti ile NATO'ya üyelik sonrasında gelişen ilişkiler görülmektedir. NATO çatısı altında, S.S.C.B.'ye ve dolayısıyla da Doğu Almanya'ya yani Demokratik Alman Cumhuriyeti'ne karşı, Batı Almanya ile yani Federal Almanya Cumhuriyeti ile müttefik olan Türkiye Cumhuriyeti Devleti'nin dış politikasında da ciddi gelişmeler ortaya çıkmıştır. Bu çalışmada, Federal Almanya Cumhuriyeti'nin Dışişleri Bakanlığı ile Türkiye'deki diplomatik misyonları arasında geçen yazışmalar başta olmak üzere; Federal Alman Dışişleri siyasi arşivinde bulunan belgelerden hareketle; 1957 seçimleri sürecinde yaşanan gelişmeler ve bu süreçte Demokrat Parti Dönemi Türk-Alman İlişkileri, tarihsel perspektif ile elçilik ve konsolosluk raporları üzerinden değerlendirilmeye çalışılmıştır.

\begin{abstract}
Turkish-German relations have been on the axis of trade and military alliance from the beginning and from the perspective of both states, great emphasis has been placed on strengthening and developing relations. Thus, in the period of Democratic Party Government that important events took place in Turkish Foreign Policy, beginning of the development of relations with the West has brought Turkey's NATO membership. In this process, Germany, which is divided into East and West after the Second World War, the relations between Turkey and the west side of the Germany has been seen after Turkey's NATO membership. Under the umbrella of NATO, against S.S.C.B. and among other countries including the German Democratic Republic named the East part of the Germany, Federal Republic of Germany named the West part of the Germany was allied with the Republic of Turkey. By the way there were lots of important cases appeared. In this study, Ministry of Foreign Affairs of the Federal Republic of Germany and especially the correspondence between their diplomatic missions in Turkey; based on the documents contained in the Federal German Foreign Office Policy archive, Turkish-German Relations in the Democratic Party Era between 1957 elections process were tried to be evaluated through historical perspective above the embassy and the consular reports.
\end{abstract}

\footnotetext{
* Dr. Öğr. Üyesi, Erciyes Üniversitesi, gesel@erciyes.edu.tr, ORCID: 0000-0001-7050-7884

Makale Geliş Tarihi (Received Date): 16.11.2020 Makale Kabul Tarihi (Accepted Date): 29.12.2020
} 


\section{Giriș}

Türk-Alman ilişkilerinin tarihi seyri dikkate alındığında, 1870-1871 Fransa-Prusya Savaş1 neticesinde 18 Ocak 1871 tarihinde Paris yakınlarındaki Versay Sarayı'nda kararlaştırılan Alman Birliği ve dolayısıyla yeni Almanya İmparatorluğu (Hawes, 2019, s. 125), kuruluşunu müteakip Osmanlı Devleti ile Prusya'dan devraldığı iyi ilişkileri devam ettirme ve geliştirme çabasında olmuştur. Bu doğrultuda karşılıklı ziyaretler ile hızla gelişen ilişkiler Osmanlı Devleti'nin I. Dünya Savaşı'na Almanya'nın müttefiki olarak girmesine uzanan bir çizgide devam etmiştir. Cumhuriyet dönemi Türkiye'sinde de önem verilen Türk-Alman ilişkileri doğrultusunda bu eski müttefik ile 3 Mart 1924 tarihinde yeni Türkiye Cumhuriyeti arasında bir dostluk antlaşması teati olunmuştur (Ökçün, 1974, s. 9). Antlaşmanın 3. maddesi uyarınca karşılıklı diplomatik temsilcilik açılması kararlaştırılmış, böylece Almanya yeni Türkiye Cumhuriyeti devletini resmen tanımıştır ("Türkiye Cumhuriyeti ile Almanya Cumhuriyeti arasında münakit...," Türkiye Büyük Millet Meclisi [TBMM], 1924, s. 483). 1920’li y1llarda sınırlı boyutta devam eden Türk-Alman ilişkilerinde çeşitli alanlarda uzman Alman bilim adamı, mühendis, mimar ve teknik uzmanın, nitelikli eleman sıkıntısı çeken yeni Türkiye Cumhuriyeti'ne gelerek bu hususta yardımcı olması ilişkilerin gelişmesinde önemli bir adım olmuştur. Bunu müteakip Versay Antlaşması uyarınca dağıtılan Alman ordusunun teknik sınıfına mensup bazı subaylar da Türkiye'ye gelerek Harp Akademilerinde görev yapmışlardır (Oran, 2019, s. 299).

Almanya'da Adolf Hitler liderliğindeki Naziler, 30 Ocak 1933'te iktidara gelmelerinin hemen ardından çıkardıkları 24 Mart 1933 tarihli 'Yetki Kanunu' (Ermachtigunggesetz) ile, başlangıçta dört yıllığına, meclis onayı gerekmeksizin anayasayı dahi değiştirebilecek yetkiler elde etmişlerdir (Eberle ve Uhl, 2015, s. 1-2). Çıkarılan bu yasa sonrasında başta Yahudiler olmak üzere pek çok insan Almanya'dan kaçmaya çalışmıştır. Bu noktada Cumhuriyetin ilk yıllarından itibaren Türkiye'de gereken alanlarda teknik anlamda destek hizmetinde bulunan Almanların sayıları hızla artmıştır. Özellikle 31 Mayıs 1933 tarih ve 2252 sayılı kanun neticesinde 1 Ağustos 1933 tarihinde kurulan İstanbul Üniversitesi'nin kuruluşunda ve gelişmesinde Hitler Almanyası'ndan kaçan Alman bilim adamlarının katkısı olmuştur (Taşdemirci, 1992, s. 7-24).

II. Dünya Savaşı'nda Avrupa'da terör estiren Nazi birlikleri dahi Türk-Alman dostluğuna zarar vermemeye dikkat etmişlerdir. Fransa'yı işgal eden Almanlar, o dönemde Türkiye'nin Paris Büyükelçisi olan ve Fransa'ya göç etmiş binlerce Osmanlı Yahudisini kurtaran Behiç Erkin ile görüşmelerinde dahi saygı ve dostluk çevresinde davranmışladır (Kıvırcık, 2007, s. 6870). Bu noktada Nazilerin Türkiye'yi bir eski müttefik olarak yeni savaşta da yanlarında görmek istediği için böyle davrandıkları şeklinde yorumlanabilir. Nitekim, Hitler'in Von Papen gibi eski bir Başbakanı Büyükelçi sıfatıyla Ankara'ya görevlendirmesinin de Türkiye'ye verdiği önemi gösterdiği açıktır (Gülmez ve Demirci, 2013, s. 226). Pek tabi bu önem Türkiye'nin savaşa Almanya'nın yanında girmesi çabasından kaynaklanmaktadır. Zira, Almanya Türkiye'nin kendi taraflarında savaşa gireceğine o denli inanmaktadır ki; Hitler 29 Nisan 1942'de Mussolini'ye “Türkiye'nin yavaş yavaş fakat kesin bir biçimde Mihver'e yaklaştı̆̆ını” söylemiştir. Hatta bu amaçla 1942 yazında Türkiye'ye silah siparişinde kullanılmak üzere yüz milyon reichmark kredi dahi açmışlardır (Deringil, 2007, s. 171). Tabi tüm bu çabalar nihayetinde boşa çıkacaktır. Türkiye, Nazi Almanya'sı ile ilişkileri kötüleştirmeden savaşın bitişine kadar tarafsızlığını korumayı başarmıştır. 
II. Dünya Savaşı'nın ardından 1945 yılında Hitler Almanya'sının yerine yeni bir Almanya'nın yanı sıra Yalta ve Potsdam konferansları neticesinde Birleşmiş Milletler'de kurulmuştur (Langlois, 2003, s. 267). Almanya'nın yeni sahipleri müttefik Kontrol Konseyi'ni oluşturan ABD, SSCB, İngiltere ve Fransa ise de, uluslararası ilişkilerde savaştan galip çıkan iki aktör, daha doğru bir ifadeyle iki yeni süper güç vardır. Nitekim, ABD ve SSCB etrafında şekillenen bu yeni dünyadan Almanya'da nasibini alarak batı ve doğu olmak üzere ikiye ayrılmıştır. 1949 itibariyle artık batıda müttefiklerin kontrolündeki Almanya, doğuda ise SSCB denetimindeki 'Demokratik Alman Cumhuriyeti' oluşturulmuştur (James, 2009, s. 181). Berlin şehri de bu taksimattan nasibini almıştır. Nitekim, 1961 yılına gelindiğinde, şehri batı ve doğu diye ayıran $155 \mathrm{~km}$. uzunluğundaki 'utanç duvarı (schandmauer)' inşa edilmiştir. 9 Kasım 1989'da Doğu Alman Hükûmeti’nin duvarın kaldırılmasına izin verdiği yönündeki açılaması ile başlayacak olan (Delius, 1990, s. 23) ve 13 Ekim 1990'da Demokratik Alman Cumhuriyeti'nin resmen sona ermesi ile Almanya'nın yeniden birleşmesine kadar geçecek olan sürede fiilen iki devletli Almanya ile Türkiye arasındaki ilişkiler, batı Almanya için direkt ve bazende NATO müttefikliği üzerinden, doğu Almanya için ise indirekt olarak yani SSCB üzerinden devam etmiştir. Bu doğrultuda çalışmanın temelini teşkil eden Alman Arşiv belgeleri, batı yani Federal Almanya Devleti’nin Berlin'de bulunan Federal Dışişleri Bakanlığı Siyasi Arşivi (Politisches Archiv des Auswärtigen Amts) menşeilidir.

Tarihsel kanıt temelli tarih metodolojisi doğrultusunda yapılan bu çalışmada, birinci el kaynak olmaları nedeniyle, Türkiye'deki Federal Almanya Büyükelçiliği ve Konsoloslukları ile Alman Dışişleri arasındaki yazışmalardan ve raporlardan yararlanılımıştır. Ayrıca, bu yazışma ve raporların Almanca'dan, Türkçe'ye transkripsiyonu yapılırken, kimi zaman raporların konu edindiği dönemi içeren hatırat ve diğer çalışmalardan da yararlanılarak, Alman diplomatlarca raporlaştırılan meseleler ile ilgili daha detaylı bilgiler verilmeye çalışılmıştır. Federal Almanya Dışişleri siyasi arşivlerinden alınan izin doğrultusunda arşivlerden çıkarılan belgeler ile yapılan bu çalışmada araştırma ve yayın etiğine uyulmuştur. Bu nedenle haricen etik kurul izni alınmasına gerek duyulmamıştır.

\section{Demokrat Parti Döneminde Türk-Alman İlişkileri}

Türkiye'nin 22 Mart 1957 tarihinde katıldığını açıkladığı Eisenhower Doktrini ile tarafını seçtiği dünya politikasında, aynı tarafta yer aldığ 1 Federal Almanya ile yakınlaşmasına dair Alman arşivlerinde Bayar ve Menderes'in Almanya ziyaretlerine ilişkin detaylı belgeler bulunmaktadır. Bunlar arasında protokol tenzip planları, ziyaret etkinlik programları, onurlarına verilen yemek davetiyeleri (bir kısmı Türkçe olarak hazırlanmış), otel faturaları vb. belgeler arşiv dosyaları içerisinde bulunmaktadır. Nitekim, Demokrat Parti döneminde NATO müttefikliği ile de pekişen Türk-Alman ilişkilerine Alman tarafının verdiği önem de, Federal Almanya'nın kurucu Şansölyesi Konrad Adenauer'in Türkiye ziyaretinde verdiği mesajlarda görülmektedir. Adenauer, 1954 Mart'ında gerçekleştirdiği Türkiye ziyaretinde iki devlet arasındaki bağlılığa işaret ederek, görüşmelerin çok faydalı olacağına işaret etmiştir (Almanya Başvekili dün Ankara'ya geldi, 1954, s. 1). Konrad Adenaur 18 Mart 1954 tarihinde Anıtkabir'i de ziyaret etmiştir (Boran, 2011, s. 275). Federal Almanya tarafindan gerçekleşen bu ilk üst düzey ziyarete ilişkin görüntüler de yine Alman arşivleri menşeilidir ${ }^{1}$. Ayrıca ziyaret esnasında

\footnotetext{
${ }^{1}$ Almanlar tarafından çekildiği anlaşılan görüntülerde Alman Başbakanın ziyaretinin yanı sıra, Türkiye ile ilgili kısa tanıtımlar da yapılmıştır. Bkz. https://www.youtube.com/watch?v=XbHwgIJEMVU\&t=62s
} 
Türkiye ile Almanya arasında birde kredi ticaret antlaşması imzalanmıştır (Adenauer ile yapılan görüşmeler sona erdi, 1954, s. 1). Türkiye'ye ziyareti oldukça verimli geçen Adenaur, İzmir'deki NATO karargâhını da ziyaretinin ardından 26 Mart 1954 günü ülkesine dönmüştür (Batı Almanya Başvekili dün şehrimizden ayrıldı, 1954, s. 1). Adenauer'in ziyaretini müteakip Türkiye Cumhuriyeti Başbakanı Adnan Menderes'te, Adeanuer'in daveti üzerine Almanya'ya iade-i ziyarette bulunmuştur. 2-9 Ekim 1954 tarihleri arasında gerçekleştirdiği kapsamlı Almanya ziyaretinde özellikle ticari alandaki ilişkiler üzerinde durulmuş ve ağır şartlar içeren bir de kredi antlaşması yapılmıştır (Irmak, 2009, s. 97). Bu doğrultuda, Menderes'in ziyareti Alman sanayicilerin, Türkiye'nin 1952-1954 yılları arasındaki ödeme sıkıntısı ve plansızlığına işaret ederek yeni bir iş birliğine sıcak bakmamaları sorunun da haledilmesine vesile olmuştur (Karavar, 2019, s. 12).

Gelişen dostluk hukuk ile karşıllklı ziyaretler noktasında Başbakanlardan sonra Cumhurbaşkanları nezdinde de gelişmeler yaşanmış ve bu doğrultuda Federal Almanya Cumhurbaşkanı Dr. Theodor Heuss 5-13 Mayıs 1957 tarihleri arasında Ankara, Bursa, İstanbul şehirlerini içeren kapsamlı bir ziyarette bulunmuştur ${ }^{2}$.

Heuss, Türkiye ziyareti esnasında Cumhurbaşkanı Celal Bayar tarafindan onuruna verilen yemekte yaptı̆̆ 1 konuşmada: "Türkiye ile Almanya arasındaki dostluk bağlarının NATO çerçevesi dahilindeki ittifakla daha da sıkılaştığını belirterek, Türkiye'deki son ekonomik gelişmeleri, Alman milletinin yakın bir alaka, hürmet ve hayranlıkla takip ettiğini" söylemiştir. Heuss, yemekte Bayar'ın Almanya'nın yeniden birleşmesi hususundaki temennilerine cevaben; Türkiye'nin Almanya'nın birleşmesi hususunda gösterdiği yakın alakaya müteşekkir olduğunu belirterek, bu düşüncenin Alman milleti için bir teselli kaynağı olduğunu söyleyerek, Von der Goltz Paşa'yı ve modern Ankara'yı kuran Alman mimarlarını, iki devlet arasındaki dostluk ve yakınlı̆̆ artıran şahıslar olarak anmıştır (Türk-Alman Görüşmeleri, 1957, s. 1-5). Ziyareti esnasında Alman Cumhurbaşkanı Heuss, İstanbul Radyosuna bir beyanat vererek; Almanya'nın Türkiye'den toplamda 740 milyon Alman markı tutarında silah siparişi verdiğini ve bunların Kırıkkale Makine ve Kimya Endüstrisi fabrikasındaki imalatına başlandığını açıklamıştır (Dr. Heuss İstanbul'da, 1957, s. 1). Bu açıklama esasen Cumhurbaşkanı Heuss'dan kısa bir süre önce 24 Mart 1957'de Türkiye'yi ziyaret eden Federal Almanya Milli Savunma Bakanı Joseph Strauss'un duyurduğu sipariştir. Zira, Strauss ziyareti sırasında Almanya'nın Türkiye'nin siparişi yerine getirebilecek durumda olup olmadığını tespit için iki ayrı komisyon gönderdiklerini ve raporların olumlu olduğunu belirtmiştir (Türk-Alman İktisadi İşbirliği, 1957, s. 1-5). Nitekim, Milli Savunma Bakanı'nın ardından Türkiye'ye gelen Almanya Cumhurbaşkanı da fiiliyata geçen bu durumu açıklamaktadır.

İki ülke içinde oldukça yapıcı ve verimli geçen Türkiye ziyaretinin ardından Heuss'un, Almanya'ya dönüşünü müteakip verdiği bir röportajında: "Türkiye'de o kadar çok Alman Bayră̆ı gördüm ki; bu kadarına Almanya'da bile nadir rastladı̆̆ımı biraz da utanarak ilave edeyim." (Dr. Heuss Bonn'a vardı, 1957, s. 1) şeklindeki ifadesi ve ziyareti sırasında Almanya Cumhurbaşkanı'na Ankara Şehri Fahri Hemşerilik payesi ve Ankara Üniversitesi'nde de Fahri Doktora payesinin tevcihi de (Ayhan, 2014, s. 72), Demokrat Parti iktidarının Türk-Alman ilişkilerine ne denli önem verdiğini gösterir niteliktedir. Heuss'un Bonn'a vardığı haberinin gazete manşetlerinden verildiği gün yine manşetten verilen bir başka haberde ise; Alman çelik

\footnotetext{
2 Almanya Büyükelçiliği resmi internet sitesi Bkz. https://tuerkei.diplo.de/tr-tr/themen/politik/0hochrangige-besuche/1793980
} 
endüstrisinin önemli isimlerinden Krupp'un Ankara'ya geldiği duyuruluyordu. Bu haber: “Alman yardım planının hazırlayıcılarından Çelik kralının ziyareti 15 gün sürecek” şeklindeki bir alt başlık ile duyurulmuştur (Krupp bugün Ankara'ya geliyor, 1957, s. 1). Bu ziyaretlerden anlaşılacağı üzere, Almanya o yıllarda ekonomik anlamda sıkıntılı süreçler yaşayan Demokrat Parti iktidarı için gerek kredi hususunda ve gerekse iktisadi ve ticari açılardan dost ve müttefik bir devlet konumundadır. Nitekim Heuss'un ziyaretini müteakip 1958 Mayıs'1nda Celal Bayar'ın Almanya ziyareti ve hemen akabinde de Menderes'in 1958 Temmuz ayındaki ziyaretlerinin de temel gayesini ekonomik ilişkiler ve beklentiler teşkil edecektir.

Demokrat Parti döneminde karşılıklı ziyaretlerle ve NATO müttefikliği ile pekiştirilen ilişkilere rağmen Federal Almanya'nın Türkiye'nin Doğu Almanya, yani Demokratik Alman Cumhuriyeti'ne yönelik politikalarından kuşku duyduğu ve yakından izlediği de konsolosluk belgelerinden anlaşılmaktadır. Çalışmanın yoğunlaştığı 1957 seçim süreci de Almanların dikkatle takip ettiği ve gelişmeleri diplomatik temsilcilikleri aracılığıyla raporlaştırdıkları bir husus olarak göze çarpmaktadır. Bu noktada elçilik ve konsolosluk raporları, Federal Alman Hükümeti'nin Türkiye'nin dış politikasının yanı sıra iç politikası ve içişleri ile de yakından ilgilendiklerini gösterir niteliktedir.

\section{1957 Seçimleri Öncesinde Siyasal Ortam}

Federal Alman Hükümeti'nin 1957 seçimlerini ve bu süreçte yaşanan olayları yakından takip ettikleri, Ankara Büyükelçiliği ve İstanbul Başkonsolosluğu tarafindan Berlin'e gönderilen raporlardan anlaşılmaktadır. Raporların içeriklerine bakıldığında, bu raporların diplomatik misyonların görevleri gereği kaleme aldıkları genel bilgilendirme amaçlı gündelik raporlar olmadıkları, aksine özellikle Federal Alman Devleti'nin Dışişleri'nin isteği üzerine ve bizzat Dışişleri Bakanı'na sunulmak üzere hazırlandıkları anlaşılmaktadır. Nitekim bu husus, Federal Almanya Devleti'nin Ankara Büyükelçiliği tarafından hazırlanarak, Berlin'e Federal Almanya Dışişleri Bakanlığı'na gönderilen 1 Nisan 1957 tarihli raporun başlık kısmında "Sayın Federal Bakan için araştırma iletildi. Dışişleri Bakanı'na sunulacak." şeklindeki ifadeden anlaşılmaktadır (PA AA 304 81 00/2, 01.04.1957).

1 Nisan 1957 tarihli 998/57 sayılı bu raporda, Federal Almanya Devleti'nin Ankara Büyükelçiliği yetkilileri tarafından raporun konu kısmına: "Başbakan Menderes ile İsmet İnönü arasında yakınlaşma" şeklinde bir açıklama yazılmıştır. Raporun devamında: "1957 Şubat'ında Türkiye Büyük Millet Meclisi genel kurulundaki bütçe görüşmelerinde, Başbakan Adnan Menderes ile önemli rakibi Cumhuriyet Halk Partisi Genel Başkanı İsmet İnönü arasında şaşırtıcı bir yakınlaşma yaşandl." şeklindeki daha önce Berlin'e gönderilmiş olan 1 Mart 1957 tarih ve 688/57 sayılı rapora atıf yapılarak, Türk siyaseti açısından alışılmadık olan bu durumun: "Türk gözlemcilerin çoğu başlangıçta bu gelişmenin uzun süreli olmadığını düşündü. Ancak son haftalarda, iki tarafin uzlaşma jestleri, haklı olarak kamu yararına halkı meşgul eden yeni bir atmosfere dönüşı̈̈. Bunun, burada bazı gözlemcilerin varsaydiğı gibi, muhtemelen 1958 baharında gerçekleşecek olan bir sonraki parlamento seçimleri için iç siyasi firsatlara yol açıp açmayacağı belirsizliğini koruyor." ifadeleri ile yorumlanmıştır. Bu noktada, raporda yer alan "Türk gözlemciler" ifadesinden kast edilenlerin, basın, muhalefet ve kamuoyu çevreleri olduğu anlaşılmaktadır. Raporlarında; Büyük Millet Meclisi Genel Kurulu'nda yaşananları ayrıntılı bir şekilde Berlin'e aktaran Ankara Büyükelçiliği yetkilileri: "Bütçe tartışmaları sırasında, hükümetin politikalarına yönelik başlıca saldırılar, 1955 sonbaharında iktidardan ayrılan ve 
parlamentoda 32 sandalyeye sahip olan Hürriyet Partisi tarafindan gündeme getirildi." derken, Cumhuriyet Halk Partisi milletvekillerini ise Hürriyet Partisi nazarında yetersiz bulduklarını ifade etmişlerdir. Bu noktada: "Onların keskin ifadeleri, Cumhuriyet Halk Partisi milletvekillerinin zaylf ve kötü düzenlenmiş konuşmalarından önemli ölçüde farklıdır." şeklindeki ifadeleri dikkat çekicidir. Bu noktada bütçe görüşmelerinin sonuna doğru genel kurulda konuşma yapan İsmet İnönü’nün: “Bazı idari tedbirlerin düzeltilmesini talep ettiği ölçülü ve ağır eleştiriler içermeyen bir konuşma yaparak, hükümetin kasten kısıtlama yapmak suretiyle üç yll önce yerel seçim yenilgileri için intikamını aldığını ifade etmiştir." Burada kast edilen Kırşehir'in vilayet statüsünün alınarak, yapılan düzenleme ile ilçe statüsüne düşürülmesi meselesidir. Nitekim, o dönemde mecliste bulunan partilerden olan Cumhuriyetçi Millet Partisi lideri Osman Bölükbaşı'nın da memleketi olan Kırşehir'in ve Osman Bölükbaşı'nın tutuklanması meselesi de 15 Temmuz 1957 tarihli İstanbul konsolosluğu raporunda konu edilmiştir.

1954 seçimlerinde iktidardaki Demokrat Parti yerine büyük bir çoğunlukla muhalefetteki Cumhuriyetçi Millet Partisi'ne oy vererek 5 milletvekilinin tamamını kazanmalarını sağlamış olan Kırşehir halkının şehirlerinin vilayet statüsünden çıkarılarak cezalandırılması (Köksal, 2004, 38-40) meselesine de yine 1 Nisan 1957 tarihli raporda kısaca değinen Alman diplomatlar; İnönü'nün konuşmasının ardından söz alarak kürsüye gelen Başbakan Menderes'in yaptığı konuşmada: "Paşa'ya" övgü yağdırdl ve dileklerinin yerine getirileceğine dair söz verdi." şeklindeki açıklamaya raporlarında yer vermişlerdir. Nitekim İçişleri Bakanlığ tarafından buna uygun bir kanun taslağı hazırlandığına dair bir bilgi notuna da raporda yer vermişlerdir (PA AA 304 81 00/2, 01.04.1957).

Hakikaten, Alman diplomatların raporlarına şaşkınlıkla yansıttıkları üzere 1957 yılı bütçe görüşmeleri esnasında yaşanan bu karşl1ıklı nezaket ve övgü içeren sözler, Demokrat parti ile Cumhuriyet Halk Partisi grupları arasında ender görülen olaylardandır. Nitekim, Almanların Başbakan Menderes'in, İnönü'ye yönelik olarak sarf ettiği sözlerin bir kısmını raporlarına yansıttıkları görülmektedir. Raporlarda konu edilen övgü dolu sözlerin tamamı ise şöyledir:

"Muhterem Arkadaşlar;

Bugün öğleden evvel Cumhuriyet Halk Partisi Genel Başkanı Sayın İönü konuştu. Bendeniz maalesef burada bulunamadım, konuşmasını yukarıdan dinledim. Ĕger burada olsaydım nasıl büyük bir tehalükle ve şevkle kendisini alkışladığımı görecektiniz. Aynı hislerle sizin de meşbu olduğunuzdan eminim" (Sükan, 1991, s. 376).

Federal Almanya Devleti'nin Ankara Büyükelçiliği yetkililerinin, Başbakan Menderes ile Cumhuriyet Halk Partisi Genel Başkanı İnönü arasındaki karşılıklı nezaket içeren bu söylemlere ise yorumları şöyledir:

“Böylesine samimiyet oldukça ilginç, Menderes'in Inönü'yü hastalıkl, hırsla takıntılı yaşlı bir adam olarak tanımladiğı ve İnönü'nün de iktidara saldırdiğg geçen yılki ifadelerle karşılaştırılırsa, bu gelişmenin arka planı sorusu ortaya çıkar."

Raporun bu noktasında 'arka plan' ifadesinin büyük harflerle yazılmış olması da dikkat çekicidir. Zira ilerleyen bölümlerde bu husus üzerine raporda epeyce yer ayrılması dikkate alınırsa, Almanların bu duruma şaşırdıkları ifade edilebilir. Nitekim, raporlarında buna yönelik olarak da: "Farklı bakış açıları olsa da, her iki tarafin da önceki gerginliklerden bir çıkış yolu bulma ihtiyacı duyduğunu gösteriyor." şeklinde yorumlamışlardır. Raporda, Türkiye'nin içinde 
bulunduğu siyasi, sosyal ve ekonomik durum üzerine de, Alman diplomatlarca yorumlar yapılmıştır. Bu noktada raporun ikinci sayfasında yer alan genel siyasi analizleri şöyledir:

"Hükümet, muhalefete yönelik sert baskıları nedeniyle iç ve dış siyasi prestijini kaybetmişti. 1956 yazında kabul edilen basın ve meclis mevzuatında yapılan değişikliklerin acımasızca uygulanmasının, muhalefetin heyecanını önemli ölçüde kısitladı̆̆ ve onu etkinliğinden yoksun biraktı̆̆ doğrudur. Bununla birlikte, bu yasalara dayanarak başlatılan bir dizi işlemin de suya atılan bir yumruktan başka bir şey olmadı̆̆ kanıtlanmıştır. Hükümet beraat kararlarını kabul etmek ve hapis cezalarının hükümlülerin popülaritesini arttırdığın izlemek zorunda kaldı. Ekonomik durumda bir iyileşme, yani fiyat artı̧̧larının sonu görünmüyor ve görünür gibi de değil. Bununla birlikte, her şeyden önce, anayasal muhalefete karşı eylemleri, yurtdlşında özellikle de Amerika Birleşik Devletleri'nde hükümetçe arzu edilmeyen düzeyde ilgi gördü. Bu nedenle amaçları muhalefeti bölmek ya da kazanmak olmalıdır. Her ikisi de şu anda deneniyor. Başbakan, hükümet cephesi dışındaki en güçlü kişilik olan ve halkın saygı duyduğu eski devlet başkanını kazanmaya çalışıyor. Hırslı, anlaşılması zor Genel Sekreter Kasım Gülek tecrit edilecek. CHP'nin diğer muhalefet partilerine, Hürriyet Partisi'ne ve Millet Partisi'ne de uzaklaşacağ umulmaktadır. Yerel gözlemciler bunu, hükümet tarafindan Kasım Gülek'in ve Hürriyet Partisi aydınlarının dişlerini kıran bir "yapıcı bir muhalefet" yaratma girişimi olarak yorumluyorlar. Son birkaç ayda, bu yılın Şubat ayından çok önce, Başbakan'ın 1958 baharında belli seçim bölgelerinde kendi adaylarını göstermekten vazgeçerek CHP'ye şimdi olduğundan (31) çok sayıda milletvekili vereceği yönündeki ısrarlı söylentiler bu görüşü destekler niteliktedir. Bunun bedeli muhtemelen rejime karşı daha olumlu bir tutum ve hükümetin ekonomi politikasının sonuçlarına yönelik keskin eleştirilerden sakınma isteği olacaktır. Adnan Menderes, CHP ile diğer muhalefet partileri arasındaki, geçtiğimiz kış bu partiler arasındaki başarısı yakınlaşma girişimleri sonucunda ortaya çıkan uçurumu şimdiden genişletmeyi başardl. Kasım Gülek de son haftalarda sessizleşti. Ancak İönü ve partisinin organları bazı demokratik hakların iade edilmesinde israr ediyor: Toplanma ve basin özgürlügü̈, orantılı temsil, radyoya erişim vb. CHP'nin taktik avantajların güvence altına almak için kamusal varsayımından ayrılmadan bu koşulların yerine getirilmesine bağlı kalmadlğı görülüyor. Çünkü muhalefet de kolay bir konumda değil. 4. Menderes kabinesinin (Aralık 1955) sadece kısa bir süre devam edeceği ve Demokrat Grubun daha fazla bölünmeyle ciddi şekilde zayıflayacă̆ı umudu, Başbakan, 3. kabinesin tartışmalı bakanlarının bir kısmını kabineye geri almayı kademeli olarak başardı ̆̆inda nihayet sona erdi."

Raporun oldukça dikkat çekici, detay ve öngörü içeren bu kısmında, Almanların Türkiye'nin iç ve dış siyasetine yönelik bilgi ve saptamaları, iktidar ve muhalefet partilerinin yakınlaşmasına yönelik kapsamlı analizleri bulunmaktadır. Üstelik belgenin başlığında belirtildiği üzere, bu araştırmanın bizzat Federal Almanya Dışişleri Bakanlığ tarafından istenmiş olması, Almanya'nın Türkiye'de olup bitenleri iyice analiz etme isteğinden kaynaklanmaktadır. Zira gerek Adenauer'in 1954 Mart'indaki Türkiye ziyaretinde ve gerekse Menderes'in 1954 Ekim ayındaki Almanya ziyareti sırasında gelişen ekonomik ilişkiler ve Almanya'nın Türkiye'ye açtığı kredi dolayısıyla Türkiye Almanya'nın yakın takibine girmiş̧tir.

Federal Almanya Dışişleri Bakanlığg tarafından bu denli geniş çapta ve iç politikaya yönelik bir araştırmanın istenmiş olmasının diğer bir nedeninin de; Federal Almanya 
Cumhurbaşkanı Theodor Heuss'un 5-13 Mayıs 1957 tarihleri arasında Türkiye'ye gerçekleştirdiği ziyaret öncesinde, Türkiye'nin içinde bulunduğu siyasi, sosyal ve ekonomik duruma dair bilgilendirilmesi amacıyla olması ihtimali de yüksektir. Nitekim, Alman Cumhurbaşkanı Heuss'un gerçekleştirdiği bu ziyaretin tarihi, raporun düzenlendiği tarihten bir ay kadar sonra olması bu görüşü destekler niteliktedir.

Ayrıca bahsi geçen raporda yaklaşan genel seçimlere dair bazı öngörülere de yer verilmiştir:

"Anti-demokratik yasalar muhalefetin eyleme geçme kabiliyetini ciddi şekilde kısitlamış̧ ve orantılı temsile doğru çă̆rıda bulunduğu seçim sisteminde bir sonraki parlamentoda daha iyi temsil şansı verecek bir değişiklik ihtimalide yok. Ancak tarafsı gözlemciler hatta hükümeti eleştirenler bile, CHP'nin tek başına veya diğer muhalefet partileriyle birlikte dahi 'hiçbir şekilde' mutlak bir çoğunluğa yaklaşma ihtimalinin olmayacağını düşünüyor. Kırsal nüfusun çoğu (toplam nüfusun yaklaşık \%75'i) Demokrat Parti'nin ekonomik kalkınma programını onayliyor, şehir sakinlerine oranla fiyat artıslarına hükümetin ekonomi politikalarının neden olduğuna daha az düşünüyor ve kendilerine verilen daha özgür dini faaliyetler için minnettarlar. Onun için yeni olan ve pratikte hiçbir zaman tam olarak gerçekleştirilemeyen demokratik haklara getirilen kısitlamalar, bir yük olarak görülmüyor. Bu nedenle, parlamento konusunda bilgili muhalefet başkanının, kendisini ve partisini bir sonraki seçimler için daha iyi başlangıç yapabilecekleri koşulları sağlamak için bir firsat aradiğı düşünülebilir."

Bu ifadelerden hareketle Alman Hükümeti'nin Türkiye ile ticari ilişkileri de göz önünde bulundurarak 1957 seçimleri hususunda atılan her adımı dikkatle takip ettikleri anlaşılıyor. Demokrat Parti'nin başarısına kesin gözüyle bakarlarken bu noktada nüfusun \%75'ini oluşturan kırsal kesimin özellikle tarımla uğraşan büyük kısmının halen Demokrat Parti'yi desteklemelerinin nedenlerinin başında Menderes'e duyulan güven gelmektedir. Zira, Demokrat Parti iktidarında çiftçiler borçlarından kurtulmuş ve alım güçleri artmıştır. Nitekim, 1953 yılının ilk yarısında dünyada buğday fiyatlarının yüksek oluşu ve bu yüzden ihracata imkân bulunmayışı söylentileri baş gösterip buğday fiyatlarının düşeceği ileri sürülünce; Başbakan Menderes Kırşehir'de bu noktaya şu şekilde temas etmiştir: (Yurtoğlu, 2014, s. 168)

"Hariçte buğday fiyatları düşüyor, eğer hükümet de fiyatları düşürmezse büyük zararlara girecektir denilmektedir. Hükümetin buğdayı 13 kuruştan alacağı şayiaları yayllmaktadır. Bu yalanlara inanmayın. Yalnız bu sene değil, fakat DP iktidarda kaldığ müddetçe, Orta Anadolu'nun başlıca mahsulü olan buğdayın fiyatını, bugünkü seviyeden aşă̆l düsürmemeği politikamızın esası olarak tespit etmişizdir. Türk köylüsünün belli başlı mahsulünü değerlendirmek, millî bir vazifedir. Ĕger bunda devlet bütçesine bir zarar hâsıl olursa, muazzam bir gayenin tahakkuku için ve uzun mahrumiyet senelerinin ıstıraplarına gögüs geren sizlerin kalkınması için, Türk milleti bu fedakârllğg seve seve yapacak ve bunu kendisine bir vazife bilecektir."

Başbakan Menderes, 1954 yılı genel seçimleri öncesi yaptığı Rize mitinginde de, buğdayı çiftçilerden 30 kuruşa alıp 20 kuruşa satacağını ifade etmiştir. Pek tabi her seçim döneminde bahsi geçen \%75'lik kesimin oyunu almak için vaatlerde bulunan Menderes'in, 1957 seçim kampanyası sırasında da, 21 milyonluk Türkiye nüfusunun 15 milyonluk kısmını teşkil eden köylülere yönelik söylemlerde bulunması doğaldır. Nitekim Menderes'in 19 Haziran 1957 tarihinde; İdare-i Umumiye-i Vilâyat Kanununun 5048 Sayılı Kanunla Muaddel 140. 
Maddesinin Değiştirilmesi Hakkındaki Kanun Münasebetiyle Türkiye Büyük Millet Meclisi Genel Kurulu'nda yapmış olduğu konuşmada da köylülerin kalkınmasına yönelik 1950'den beri yaptıkları çalışmaları, geçmişle mukayese ederek aktarmıştır (Neziroğlu ve Yılmaz, 2014, s. 811-812). Bu doğrultuda, Alman diplomatların raporlarında belirttiği; "Kırsal nüfusun çoğu (toplam nüfusun yaklaşık \%75'i) Demokrat Parti'nin ekonomik kalkınma programını onayllyor" şeklindeki ifadelerinin zemininin sağlam olduğu ifade edilebilir. Zira 1957 seçim sonuçları da bunu adeta bu ifadeyi kanıtlar nitelikte sonuçlanacaktır.

1 Nisan 1957 tarihli raporun son kısmında ise; İktidar ve Muhalefet arasındaki yakınlaşmaya yönelik olarak yapılan yorum şöyledir:

"Yerel gözlemciler ve gazetecilerden oluşan geniş çevreler, bu iç siyasal 'çözülme’nin süresine şüpheyle yaklaşıyor. Yönetilebilen bir muhalefetle çalışma girişimleri Türkiye'de yeni değil. Son olarak, Kasım Gülek'in 1955 yazında ABD'den dönüşünün ardindan Demokrat Parti ile CHP arasında bir anlaşma mümkün değilmiş gibi görünmedi; ancak bu rüya, parti liderlerinin acı polemiklerinde kisa sürede ortadan kayboldu. Bu kadar çok özdenetim gerektiren bir oyunu uzun vadede uygulanabilir kılmak için hırs ve güç arasında çabalamak çok zordur, ancak pratik nedenlerden ötürü en azından geçici bir işbirliği tavsiye edilebilir."

25 Mayıs 1957 günü Başbakan Menderes, Sivas’ta yaptığı bir konuşmada seçimlerin yakın olduğunu ifade etmesi ile birlikte, muhalefet partileri için yeniden işbirliği gündeme gelmiştir (Eroğul, 2003, s. 197). Böylece Demokrat Parti ve CHP arasındaki yakınlaşma yerini o döneme kadar görülmemiş sertlikte geçecek bir seçim rekabetine bırakmıştır.

Menderes'in seçimlerin yakın olduğunu beyan ettiği konuşmasından bir hafta önce ise Cumhuriyetçi Millet Partisi Genel Başkanı Osman Bölükbaşı seçim kampanyasını ilan etmişti. Bölükbaşı'nın seçim bölgesi olan Kırşehir'in vilayet statüsünün yeniden tesisi için meclisteki girişimler neticesinde 12 Haziran 1957 tarihinde, Kurşehir yeniden vilayet haline getirilmiştir (Artvinli, 2004, s. 67). Bu durum Menderes'in Kırşehir halkının oylarına yönelik bir hamlesi olarak yorumlanmıştır.

\section{Osman Bölükbaşı'nın Tutuklanması}

Kırşehir'in yeniden vilayet statüsüne alınmasına yönelik kanun teklifi görüşmeleri esnasında CMP lideri Osman Bölükbaşı Kozaklı ve Hacıbektaş ilçelerinin Nevşehir'de kalmasına oldukça sert itirazlarda bulunmuştur. Nitekim Bölükbaşı'nın bu muhalefeti, iktidar cenahında meclise hakaret olarak değerlendirilmiş ve Bölükbaşı'na bu gerekçe ile üç oturum genel kuruldan men cezası verilmiştir. Genel kuruldan çıkarılan Bölükbaşı, koridora çıktığı sırada meclis idare amirlerinden ve DP Balıkesir Milletvekili Ahmet Kocabıyıkoğlu tarafından kendisine sözle sataşılmış, Bölükbaşı'nın da cevap vermesi üzerine tartışma büyüyerek yumruklaşmaya dönüşmüştür. Olay esnasında CMP Genel Başkanı Osman Bölükbaşı'nın koridorda sarf ettiği sözler meclisin manevi şahsiyetine hakaret sayılarak hadise adliyeye intikal ettirilmiştir. Savcılık da, Bölükbaşı'nın dokunulmazlığının kaldırılması istemiyle Adalet Bakanlığı'na başvuruda bulunmuştur. Hemen akabinde harekete geçen Bakanlık fezlekeyi Meclise göndermiş ve Meclisin Anayasa ve Adalet Komisyonlarından oluşan bir karma komisyon 11 e karşı, 13 oyla Bölükbaşı'nın dokunulmazlığını kaldırmıştır (Ayhan, 2006, s. 57-58). 
Dokunulmazlığının kaldırılmasının ardından tutuklanan Osman Bölükbaşı ile ilgili olarak özel bir rapor hazırlayan Federal Almanya'nın İstanbul Başkonsolosluğu yetkilileri, 15 Temmuz 1957 tarihli belgenin başlığını: 'Osman Bölükbaşı'nın Tutuklanması' şeklinde belirlemişledir (PA AA304 81 00/1, 15.07.1957). Raporun içeriği ise şöyledir:

"Türkiye Büyük Millet Meclisi, yaz tatilinden önceki son oturumunda, 24 Haziran 1957'de muhalefetteki Cumhuriyetçi Millet Partisi Genel Başkanı Osman Bölükbaşı'nın dokunulmazlığını kaldırdı. Bölükbaşı, önceki sorgulamanın ardından 2 Temmuz'da tutuklanarak Ankara'daki merkez cezaevine götürüldü.

1954 'te geçici bir yasağın ardından yeniden kurulan Millet Partisi, parlamentodaki en küçük gruptur. Sadece Kırşehir seçim bölgesinde 4 sandalye kazandl. Parti temkinli de olsa, İslam'a inananlarin geleneklerine ve dinsel duygularina hitap ediyor. 43 yaşındaki matematikçi ve Nancy Üniversitesi mezunu liderleri Bölükbaşı, 1945 'ten beri siyasi hayatın içinde.

Her iki olay da - dokunulmazlığın kaldırılması ve parti liderinin tutuklanması - üç muhalefet partisi, Cumhuriyet Halk Partisi, Hürriyet Partisi ve Cumhuriyetçi Millet Partisi ve Türk kamuoyunda büyük heyecan yarattı. Hükümetin Bölükbaşı'na müdahalesi bu çevrelerde muhalefet partilerini sindirme girişimi olarak görülüyor; $B u$, her şeyden önce, 1956 baharından bu yllın sonbaharına kadar ertelenen ve yaklaşan seçimlerin görünümüdür.

Bölükbaşı aleyhine alınan tedbirlerin gerekçesi, 12 Haziran 1957 tarihli Büyük Millet Meclisi oturumunda yaptı̆̆ söylenen açıklamalarla ifade edildi. Bu oturumda, 1954 seçimlerinden sonra hükümetin inisiyatifiyle muhalif oy kullanmanın bir 'ceza' olduğu anlaşılan Kırşehir'e (Ankara'nın güneydoğusu) vilayet karakterini geri kazandıracak bir yasa tartışldl, zira yerel halkın muhalefete oy vermeleri nedeniyle bir ceza olarak vilayet statüsü alınmıştl.

12 Haziran'daki oturumda Bölükbaşı'nın bu konudaki tavırları nedeniyle milletvekillerine meclis kürsüsünden ciddi kişisel suçlamalar yönelttiği ve daha sonra Millet Meclisi koridorunda sözlerini tekrarladiğı söyleniyor. Hükümet bunu Türk Ceza Kanunu'nun 159. maddesi anlaminda suç olarak değerlendiriyor. Bu fikra, Büyük Millet Meclisine aleni hakaretten suçlu bulunanlara '1 yıldan 6 yıla kadar hapis cezası' öngörmektedir.

Meclis komisyonunun bir önceki toplantısının ardından ve Inönü’nün Bölükbaşı lehine müdahalesinin özellikle dikkate değer olduğu, olağanüstü firtınalı bir tartışmanın ardından, Kırşehir Milletvekili'nin dokunulmazlı̆̆ 49 oya karşılık 247 ile kaldırıldı ve yaklaşık 100 milletvekili oylamaya katılmadı. Bu, onun bir hafta sonra tutuklanması için yasal imkânı sağladı. Muhalefetin iddia ettiği gibi, ki muhtemelen yanlış değil, bu eylemin Başbakan Adnan Menderes 'in kişisel bir girişimi olduğu düşünülüyor.

Raporda açıkça ifade edildiği üzere Alman diplomatların, Osman Bölükbaşı'nın tutuklanmasının yaklaşan seçimlerin habercisi olduğu öngörüsü kısa sürede gerçekleşecektir. Zira Demokrat Parti grubu, 5 Eylül 1957 günü yapılan meclis grubu toplantısında, normal şartlarda 1958 baharında yapılacak olan milletvekili seçimlerini, 11 Eylül tarihinde gündeme getirmeye karar verdi. Seçim günü olarak da 27 Ekim Pazar günü kararlaştırılmıştı (Yücel, 2001, s. 124). 


\section{1957 Seçim Süreci}

Demokrat Parti iktidarının erken seçime gitmeye karar verdiği günlerde, 7 Eylül 1957'de partinin dört kurucusundan biri olan M. Fuad Köprülü'nün istifası, kamuoyunda bomba tesiri meydana getirdiği şeklinde yorumlanmıştır. Köprülü istifasında:

"Hayatımın on yılından fazlasını sarf ettiğim Demokrat Parti programından ayrılmış, eski hüviyetini tamamen değiştirmiş, olan bu günkü D.P. zihniyeti ile uyuşmak, benim için imkânsız olduğu cihetle D.P.'den çekiliyorum... Demokrasi nizamına iman etmiş bütün Türk vatandaşlarının, aralarındaki her türlü ihtilafları bir tarafa atarak, bu gaye uğrunda işbirliği yapmaları bir vatan borcudur” (Albayrak, 2004, s. 295).

Köprülü'nün Demokrat Parti'den istifasını müteakiben, bazı DP milletvekilleri de partilerinden istifa etmişlerdir. İstifalarla bir hayli yıprandığg görülen Demokrat Parti Hükümeti, seçimlerde oy beklentisi içerisinde olduğu bölgelerde çalışmalarına hız verdi. Bu doğrultuda, Menderes hemen her gün bir şehirde fabrika açılış ve temel atma törenleri ve gecekondu ve yahut toplu konutların tapu teslim törenlerine iştirak etmiştir (Albayrak, s. 296).

Bu noktada, Alman diplomatların 28 Ağustos ve 14 Eylül 1957 tarihli raporlarında üzerinde durdukları Demokrat Parti’nin erken seçim kararının nedenleri ise şöyle sıralanmıştır:

“iktidar partisinin seçimleri öne çekme yönündeki sürpriz kararında aşağıdaki nedenler belirleyici olabilir:

1. Parlamento seçimlerinden önce dış politika alanında hükümetin kaçınılmaz felç olması Türkiye üzerinde olumsuz bir etki yaratabilir - özellikle de beklendiği gibi, öngörülebilir gelecekte Kıbrıs konulu yeni bir üçlü konferans toplanırsa.

2. 50 milyon dolarlık tüketim malları ve yedek parçaların kredi bazında veya özel takas yoluyla sunulmamasl, arz durumunun daha da kötüye gideceğini ve bunun hem tarım hem de kent nüfusu üzerinde hoş olmayan bir etki yaratacă̆ını düşündürmektedir. Devletin tahıl satın alma fiyatındaki yaklaşık \%30’luk artış da, kış boyunca kazançlarda buna karşıllk gelen bir artış olmadan önemli fiyat artışlarını öngören faktörlerden yalnızca biridir.

3. Muhalefet partileri arasındaki işbirliğine karşı yasal tedbirler, 2 - 11 Eylül arasındaki olağanüstü parlamento oturumu sirasında komisyonlarda ve genel kurulda da zorlanmadan alınabilir (PA AA 30481 00/1, 14.09.1957).

Nitekim raporda belirtilen; Muhalefet partileri arasındaki işbirliğine karşı yasal tedbirler noktasında DP Hükümeti, 13 Eylül 1957'de meclis genel kurulunda kabul edilen yeni seçim kanunu ile yaklaşan seçimlerde muhalefeti zora sokmak gayretinde olmuştur. Bu doğrultuda, Demokrat Parti bu yeni seçim yasası ile hem muhalefetin güç birliği yapmasının hem de Hürriyet Partisi’nin kendisinden oy koparmasının önüne geçmeye çalışmıştır (Sezen, 1994, s. 245).

Meclis'te onaylanan yeni seçim kanununa Alman belgelerinde şu şekilde yer verilmiştir:

"11 Eylül seçim yasası değişikliği, 1950'den beri yürürlükte olan seçim yasasında, her halükarda tam olarak liberal olarak adlandırılmayan aşağılaki değisşiklikleri öngörmektedir: 
1. Siyasi partiler, parti örgütlerinin bulunduğu tüm seçim bölgelerinde aday listeleri hazırlamalıdır; Aday listeleri, seçim bölgesinde milletvekillerinin olacă̆ kadar aday içermelidir (üç muhalefet partisinin her birinin 67 seçim bölgesinin çoğunda kendi örgütü vardır).

2. Değişikliğin açılklanmasından iki ay önce veya sonra bir siyasi partiden ayrllanlar, yaklaşan parlamento seçimlerine katılamazlar.

3. Bă̆ımsız adaylar artık siyasi partilerden birinin listelerinde eskiden olduğu gibi seçime katılamıyor. Seçmen bağımsız bir aday için oy kullanırsa, seçim bölgesindeki diğer adaylara oy vermekten vazgeçmek zorundadır - İstanbul'da 36 milletvekili seçilir. Bağımsız adayların çoğu hükümeti eleştiriyor."

Seçim kanunundaki değişikliklerin yanı sıra, 1957 seçimlerine girecek olan partilere dair de oldukça ayrıntılı bilgiler içeren, 14 Eylül 1957 tarihli elçilik raporunun ikinci sayfasından itibaren aktarılan notlar ise şöyledir:

"Muhalefet partilerinin bu hükümlere tepkisi halen devam ediyor. Ayrı aday listeleri sunacak olsalar da, seçim yasasında buna izin verilmese de, her seçim bölgesinde seçim propagandasını yalnızca bir parti listeleri üzerinde yoğunlaştırmaya çalışacaklarına inanıllyor. Her yerde büyük öfkeye yol açan seçim yasasıyla muhalefet, hükümetin halkın gözünde kendisine zarar verdiği de kanaatindedir. Bu husus, Muhalefetin ciddi anlamda zayıflayacă̆ını gösteriyor. Fuat Köprülü'nün Demokrat Parti'den istifasl, başlatılanlar için beklenmedik olmasa da bomba gibiydi. Profesör Köprülü, Demokrat Parti'nin dört kurucusundan Halk Partisi'nden ayrlan ilk kişidir. Türkiye'de demokrasinin gerçekleşmesine yönelik sürekli, korkusuz savunuculuğu ve uzun süreli dışişleri bakanliğl ona genç entelektüel çevrelerin çok ötesine geçen bir itibar kazandırdı. Köprülü başlangıçta siyasi hayattan uzak durmak ister; milletvekili adaylığı zaten hariç tutulmuştur.

Ankara ve İstanbul'da olağanüstü gerilim var ve bu ülke genelinde hissediliyor. Son birkaç gün içinde bazı diğer Demokrat parti milletvekilleri de partilerinden istifa etti. Bir yanda muhalefet partilerinin liderleri, diğer yanda demokratik parti yönetim kurulu, müzakere için neredeyse her gün toplanıyor. İlgili herkes, seçimin sonucunun aslında açık olduğu konusunda hem fikir.

\section{Seçime katılan Türk partilerinin başlangıç pozisyonları șu șekildedir:}

Celal Bayar ve Adnan Menderes'in Demokrat Partisi önceki ikna gücünün çoğunu kaybetti. 1950'de çoğunlukla onlar destekleyen eğitimli sinıflar, hükümetin antidemokratik yasalarından (basın ve toplanma özgürlüğ̈̈, yargl, üniversiteler, radyo kullanımı, seçim yasası alanlarında) hayal kırıklı̆ı̆na uğradı; Fiyatlardaki artış, hükümet destekçilerinin, yani köylülerin çoğunluğu arasında da dikkat çekicidir. Dahası, hükümetin muhaliflerine karşı sert eylemi, kırsal nüfusun bazı kesimleri de dâhil olmak üzere, kademeli olarak korku uyandırmaktadır.

Bunun dışında, bazı darbelere rağmen parti oybirliğiyle Adnan Menderes 'in arkasında duracak ve kalkınma çabaları ve tarım politikasıyla Anadolu nüfusunun büyük bir bölümünü kazanmaya devam edecek. 
Atatürk'ün Partisi Cumhuriyet Halk Partisi, 1950 ve 54'teki beklenmedik yenilgilerin ă̆ır darbelerinden büyük ölçüde kurtuldu. Özellikle son birkaç ayda, başkanları İsmet İönü yönetiminde, iktidarının son yıllarında kaybettiği güvenin bir kismını ılımlılıkla nasıl yeniden kazanacağını anladı. Destekçileri kısmen kasaba halkından, kısmen de eski Birlik Partisi'ne sadık kalan geleneksel cumhuriyetçi kırsal çevrelerden geliyor.

Hürriyet Partisi 1955'te Demokrat Parti'den ayrıldı ve destekçileri esas olarak akademisyenlerdir. Ülkede parti teşkilatının kurulması son altı ayda güçlü bir şekilde hızlandl. Bununla birlikte, geniş bir seçmen kitlesine hitap edecek hem bir lider hem de bir parti programı eksikliği var. Mevcut olan çoğunluk sisteminde, diğer muhalefet partileriyle güçlerini birleştirmemiş olsaydl, seçim beklentileri zaylf olurdu.

Ülkenin dini açıdan gerici, milliyetçi partisinin ülke çapında dağınık bir takipçisi var. Son yıllarda İslami - Ortadoğu mirasına daha fazla odaklanma eğiliminin yanı sira mükemmel bir konuşmacı olarak tanınan Başkanı Bölükbaşı'nın haksız yere tutuklanmasindan da yararlaniyor. Bu seçimlerde oy oranlarl (1957=\% 7) alabilirler.

3 Eylül'deki Büyük Millet Meclisi toplantısının ardından, üç muhalefet partisi, ülkedeki demokratik olmayan durumlar knayan ve bir sonraki parlamentoda anayasayı revize etmek için önlemler alan ortak bir bildiri yayınladı: temel demokratik hakların açık, güvenli bir şekilde formüle edilmesi, bir anayasa mahkemesinin kurulması, bağımsız bir yargının korunması, İki meclisli sistemin yanı sıra oy hakkının getirilmesi. Yeni seçimler en geç iki yıl sonra yapılacak. Ucuz demagojiler içermeyen bu kusursuz ifadeli duyuru geniş bir karşıllı buldu.

Seçim yasasında yapılan değiş̧iklik muhalefetin iş birliği yapmasını, yani hükümeti eleştiren herkesi bir araya getirmesini ve onları çoktan seçmeli oylama sistemine dâhil edebilmesini şekilde engelliyor. Yine de firsatlart var, ancak son dakika seçim boykotu, hükümetin bunu daha fazla engellemesi durumunda oldukça olası."

Raporun son kısmında ise seçim sonucuna yönelik olarak Alman diplomatların yorumlarına yer verilmiştir:

"Seçim sonucunu köylerin ve küçük kasaba sakinlerinin tavrl belirleyecek. Önemli sorular şunlardir:

1. Dünyada fiyatlardaki artış kırsal nüfusa nasıl yansıdı ve Demokrat Parti'nin getirdiği sübvansiyon sistemini bozdu mu?

2. Geniş kitlelerin bakış açısına göre, hükümet muhalefete karşı mücadeleyi aşırı mı zorlad, yoksa önlemleri bu sefer tekrar kazanmasina yardımci olmaya uygun mu?"

Siyasi Partilerin 1957 Milletvekilliği Genel Seçimleri için kampanyaları hızla devam ederken, Alman diplomatların 1 Nisan 1957 tarihli raporlarında belirttikleri gibi tıpkı 1954 seçim döneminde olduğu gibi, Menderes ve İnönü arasındaki sert ifadeler de seçim meydanlarında yerini almıştır. Başbakan Menderes, 13 Ekim 1957'de Trabzon'da ve 14 Ekim 1957 günü de Giresun'da yaptığı seçim mitinglerinde İsmet İnönü'ye yönelik olarak:

“Ísmet Paşa buhran diyor. Buhran, Paşa'nın kafasındadır. İsmet Paşa hastadır. Malta hummast, Asya gribi bir hastalı̆̆a tutulmuştur. Onun hastalı̆̆ının adı 'Dar-ül İktidar'dır. İsmet Paşa hayatının hiçbir devrinde bir gün dahi, vatandaşın serbest reyi 
ile işbaşına gelmiş değildir. İlk serbest seçim yapıldığı günde işbaşından uzaklaştırılmıştır." (Şeyhanlıŏ̆lu, 2011, s. 217)

Seçim kampanyaları ile DP ile CHP ve Menderes ile İnönü arasındaki ilişkilerin eskiye dönmüş olması da Alman diplomatların raporlarına yansımıştır. 1957 yılı başındaki bütçe görüşmeleri sırasında birbirlerine iltifat eden iki liderin yerinde yeller esmektedir.

Milletvekilliği Genel Seçimleri öncesinde Alman diplomatların Berlin'e gönderdikleri son rapor 15 Ekim 1957 tarihlidir. Seçimlerin 27 Ekim'de yapılmasını müteakiben seçim sonuçlarını bildirmek için gönderecekleri raporlara çalışmada yer verilmemiştir. Ancak raporlardan anlaşıldığı kadarıyla, Almanların seçim sonuçlarına yönelik tahminlerinin büyük oranda doğru çıkmasına rağmen bu duruma kendilerinin pek de şaşırmadığını belirtmek gerekir.

'Türkiye'deki seçim kampanyası' konu başlıklı 15 Ekim 1957 tarihli ve Federal Almanya’nın Ankara Büyükelçiliği imzalı raporda ise: (PA AA 304 81 00/1, 15.10.1957)

İktidar partisi ve muhalefetin durumlarına dair özet bilgiler verildikten sonra, aday listeleri üzerinde durulmaktadır. Burada yeni kabineden yer alması muhtemel isimler de zikredilmektedir. Devamında ise partilerin seçim kampanyası yöntemleri üzerinde durularak, partilerin slogan ve afişleri Türkçe'den Almanca'ya çevirebildiği ölçüde aktarılmaya çalış1lmıştır. Raporun son bölümünde ise seçim tahmini yapılmış olduğu görülmektedir:

"Türkiye seçim kampanyası tüm hızıyla devam ediyor. Başbakan Adnan Menderes ve onun ekonomi politikası konusundaki tartışmalar, 1954'te olduğundan daha fazla yoğunlaştı.

\section{Iktidar Partisi:}

Millet Meclisinde Demokrat Parti Grubu, parlamentonun erken feshini onayladı çünkü kesinlikle yeni ekonomik zorlukların geleceğinden endişe ettikleri için artık meclis çoğunluğunu kazanma şanslarının, bir kış sonrasına göre daha fazla olduğuna Adnan Menderes'i ikna edebildiler. Menderes, özellikle destekçileri arasinda her zaman zeki bir taktikçi olarak kendini göstermiştir. Onu dengeleyebilecek tek kişi, Prof. Fuat Köprülü, başlangıçta surat asmış ve sonunda ortak olarak kurdukları partiden dikkat çekici ayrılış anını kötü bir şekilde seçmiş, yani çok uzun süre geciktirmiştir. 'Köprülü kanunu' olarak nitelendirilebilecek seçim yasasına yapılan eklemeler, onun başka bir partiden aday olmasına imkân tanımıyor.

Köprülü şimdi Demokrat Parti eleştirisini kamuoyuna açıkladl. İstanbul gazetesi "Vatan"daki yazısından ve yarı resmi "Zafer" in cevabindan bir alıntı ektedir. Demokrat Parti'den önceki birkaç milletvekilinin istifast, aday listesindeki kişisel hayal kırkklkklartyla ilgili olabilir.

Demokrat Parti, 1954 'te olduğu gibi, bazıları pekiyi düzenlenemeyen bir dizi açılış ve temel atma törenleriyle örneklendirilecek olan tanınmış ekonomik yükseliş şarkısıyla seçim kampanyasına liderlik ediyor. Tüketim mallarının ithalatındaki propagandacı rahatlama, özellikle gıda pazarında endişe verici kıtlıklar ve fiyat artışlarıyla karşılaştırılmaktadır. Şehirlerde hükümete karşı olan hava pek sıcak değil, ancak kararın çiftçilere ait olduğu iyi biliniyor. 


\section{Muhalefet:}

Millet Meclisi'nin dă̆llmasının ardından, Ankara'da üç muhalefet partisi de, hükümete karşı birleşik cephe arzusunun vurgulandiğı parti kongreleri düzenledi. Parti liderlerinin her biri diğer partilerin kongrelerini ziyaret etti. Açıktır ki, muhalefetin elinde bulunan çok sayıda becerikli avukatlar bile seçim yasasına yapılan yeni eklemelerle ortak bir listeyi veya birleşik cepheyi mümkün kılacak bir formül bulmayı başaramadl. Bunun tek yolu, bir seçim bölgesindeki iki muhalefet partisinin taraftarlarına ü̧̈üncü, yani en umut verici muhalefet partisine oy vermeleri ve yasaya göre sunulması gereken kendi listelerini sona koymaları talimatıydl. Ancak Hürriyet Partisi'nin, bir zamanlar totaliter devleti destekleyen Cumhuriyet Halk Partisi'nin güvensizliği çok canlı olduğundan ve 74 yaşındaki İsmet İnönü'nün kişiliğinin ă̆ırlı̆̆ına eşit bir şey olmadı̆̆ını bildiğinden, böyle bir yaklaşıma pek sıcak bakmadı. İnönü'nün karşı çıkacak aynı değerde hiçbir şeyi yok. Aktif ama açık sözlü demagog, Halk Partisi Genel Sekreteri Kasim Gülek'in daha sonra hükümetin kurulmasinda öncü bir rol oynamasina izin verme konusundaki isteksizliği, kendi partisinin çevresine de yayllyyor. Öte yandan, Cumhuriyet Halk Partisi'nin bu utançtan geleceğin hükümet başkanı olarak önerdiği Profesör Şemsettin Günaltay, eski polis devleti ve devletçi formunda çok azının özlediği İn̈̈nü rejiminin son hükümet başkanıydl. Muhalefet partileri, yalnizca Demokratları yenilgisi durumunda uygulanmasi gereken belirli ilkeler üzerinde anlaştılar; Öncelikle mevcut seçim yasasının nispi temsil açısından yeniden şekillendirilmesi ve yeni seçimler için en geç 6 ay içinde ulusal meclisin feshedilmesi kararı var. Cumhuriyet Halk Partisi'nin adayları bu vaadi açıkça taahhüt ettiler.

Kırsal kesimde önemli şansı olan Millet Partisi, belagatli lideri Osman Bölükbaşı'nın tutuklu olması nedeniyle engelleniyor. Millet Meclisine hakaretten açılan mahkeme işlemleri gizlice yapılmayacaktır, Ancak basının bununla ilgili herhangi bir haber yapmasina izin verilmiyor.

\section{Aday listeleri:}

Aday listeleri hazırlanırken önemli ön kararlar alınır; her iki taraf da, parti genel merkezinin veya parti liderlerinin önceki tüm teminatlarının aksine çok fazla alan birakmaktadır.

Demokrat Parti'nin 8 Ekim'de yayınladĭ̆ı aday listelerine bakıldığında, Menderes'in Istanbul'daki Yunan azınlığa karşı gerçekleşen olayların ardından, Kasım 1955 'in kara günlerinde sahip olduğu son milletvekillerini de ihraç etme firsatın şimdi kullandiğı ortaya çlklyor. Bir yll önce Ístanbul ve Ankara'da derinlemesine kentsel planlama yenilikleri ele alındiğında, Başbakan'ın sürekli yoldaşı olarak biline ünlü Türk mimar Emin Onat'ın da aralarında bulunduğu 144 eski milletvekili artık aday gösterilmedi. Türkiye başkentinde propaganda izlenimi veren bu projeler, ciddi eleştirilerle karşılaşmış ve istenen etkiyi yaratmanın çok uzağındadır. Yeni adaylar arasında bazı üst düzey yetkililer var, Görünüşe göre bakanlık makamı alacak kişiler: İşletmeler Bakanlığ Müsteşarı Necati Topçuoğlu ile Başbakanlık Müsteşarı Ahmet Salih Korur, Adalet Bakanlığı Müsteşarı Hadi Tan, İçişleri Bakanlı̆̆ı Müsteşarı Dilaver Argun; Çalışma Bakanlığı Müsteşarı Hulusi Timur, önceki Basın-Yayın Radyo ve Turizm Genel Müdürü, Dr. Halim Akyol, Anadolu Ajansı Genel Müdürü Şefik Arzı, Eski Paris 
Büyükelçisi ve eski Dışişleri Bakanı Numan Menemencioğlu, Beden Terbiyesi Genel Müdürü Nizamettin Kırşan, Milli Eğitim Bakanlı̆̆ Yüksek Öğretim Genel Müdürü Faik Binal, TBMM Genel Sekreteri Refet Sezen. Seçim yasası gereği bu görevlilerin tamamı adaylık kabul edilmeden görevlerinden istifa etmek zorunda kaldl.

Yakın zamanda emekli olan askeri personel adaylar: önceki Genelkurmay Başkanı İsmail Hakkı Tunaboylu; Deniz Kuvvetleri Komutanı Sadık Altıncan; Hava Kuvvetleri Komutanı Fevzi Uçaner, Kara Kuvvetleri Komutanı Nurettin Aknoz.

Bilim çevrelerinden aşağıdakiler belirlendi: Ankara Üniversitesi eski Rektörü İzzet Birand; İzmir Ziraat Fakültesi Dekanı Vamik Tayşi; Veteriner Hekim Süreyya Tahsin Aygün ve Doktor Nüzhet Şakir Dirisu.

1956 sonbaharında görevden alınan Ankara Siyasal Bilgiler Fakültesi eski Dekanı Profesör Turhan Feyzioğlu, Cumhuriyet Halk Partisi için aday; ayrıca eski Büyükelçi ve tanınmış yazar Yakup Kadri Karaosmanoğlu. Burada dikkat çekici olan, 1950 yılına kadar Başbakan yardımcısı olan Prof. Nihat Erim'in geçen yıl Menderes'e Kıbrıs konusunda danışmanlık yapmasına ve Menderes'in onu kazanmayı başarmasına rağmen yine partisinden (CHP) aday olmasıdır.

Demokrat Parti'den ayrlan Demokrat Parti üyelerine ek olarak, Hürriyet Partisi adaylarl, Ankara Siyasal Bilgiler Fakültesi eski ögretim üyeleri; Aydın Yalçın, Muammer Aksoy, Şerif Mardin (Eski protokol başkanı ve Hartum'daki mevcut Büyükelçinin oğlu) ve Prof. Köprülü'nün damadl Coşkun Kırca. Ankara'da Büyükelçiliğin Avukatı Prof. Dr. Hikmet Belbez'in eşi Belbez Hanım aday. Kadınlar; Demokrat Parti 9, Cumhuriyet Halk Partisi 8, Hürriyet Partisi 6, Millet Partisi 15, olmak üzere aday gösterildi.

\section{Seçim kampanyast yöntemleri:}

Önceki seçimlerin aksine bu sefer afiş de rol oynayacak. Demokrat Parti, Celal Bayar ve Menderes'in portreleri ile çalışlyor, Muhalefet ise:

Cumhuriyet Halk Partisi: "Ne yazık ki Traktörü öküzle çekiyoruz", "Mal yok, milli korunma kanunu var”, sloganlarıla. Kuyruk, kuyruk, kuyruk, bu mu bolluk?"

Hürriyet partisi: "Basın hürriyetini boğazlayanlar, sandıkta yalnız günahlarını bulacaklar!”, "Nalını mıhsız, samanını bağsız, hastayı ilaçsız, talebeyi kitapsız, şehirliyi meskensiz birakanlara artık yeter!"

Millet Partisi: "Celal Bayar 1948'de demişti ki: 'Eğer yarın DP iktidara geldiği takdirde vaatlerini yerine getirmezse ve siz onu alaşağı etmezseniz milli vazifenizi yerine getirmemiş olursunuz...' "Vatandaș! Milli vazifeni yerine getir."

Muhalefet seçim manifestoların yayıyor; Cumhuriyet Halk Partisi'nin ki örnek olarak ekte gönderildi; iktidar partisi henüz programlı bir açıklama yapmadı.

\section{Seçim tahmini:}

Bir seçim tahmini için somut bir gösterge yok. Ancak şu söylenebilir: Kamuoyu yoklaması yapmak ve anket sonucu yayınlamak yetkililer tarafindan yasaklanmıştır. Şimdiye kadar destekledikleri Demokrat Parti'den kursal kesimdeki seçmenlerin de şaşırtıcı bir şekilde sapma olasılığı tamamen göz ardı edilemez. Her halükarda 
muhalefet partileri taşra teşkilatını kurmayı ve köylerde yer edinmeyi başardılar. Muhalefet partileri, istikrarsız arz durumundan ve Menderes hükümetinin diktatörlük yöntemlerinden giderek artan şekilde fark edilen memnuniyetsizliğinden yararlanmaya çalışıyor. Bununla birlikte, Menderes'in muhalifleri için, aralarındaki çekişmeler zaman zaman şiddetli bir şekilde patlak vermesine rağmen, seçim yasasında yapılan son değişikliklerin bir sonucu olarak üç muhalefet partisinin ayrı ayrı savaşmaya zorlanması nedeniyle ezici bir zafer sonucu öngörülmemektedir.

Ancak genel görüs, Menderes ve Demokrat Parti'nin, büyük şehirlerde oy kaybının olması muhtemel olsa bile, seçimlerdeki mevcut çoğunluk oylama sisteminin yardımıyla yeniden galip geleceği yönündedir.

Türkiye'nin gelecekteki hükümetini kim oluşturacak olursa olsun, Batı ve onun savunma ittifaklarıyla sık bir ilişki içinde olan, daha önce izlenen diş politika yolundan hiçbir şekilde geri dönmesi beklenmez. Ekonomi politikası alanında, muhalefet yarışı kazanırsa, belirli reformlar gerçekleştirme konusunda daha büyük bir isteklilik beklenebilir. Bununla birlikte, kısa bir süre sonra, iyileştirilmiş seçim yasası altında yeni bir seçime kendini adadı̆̆ı için, bir kemer sıkma politikast yoluyla kendisini tekrar popüler hale getirme cesaretine sahip olması muhtemel değildir, bu nedenle ekonomik nitelikte sert önlemler ancak daha uzun bir süre sonra gerçekleşir.

Alman diplomatlar tarafindan 1957 seçimlerine yönelik olarak hazırlanan en kapsamlı rapor olduğu anlaşılan 14 Ekim tarihli bu raporun, 1954 seçimlerinde beri Türkiye'nin iç siyasetinden ilgisini eksik etmeyen Federal Alman diplomatlarının konuya ne denli hâkim oldukları göstermesi açısından dikkat çekici olduğu ifade edilebilir. Ancak burada asıl dikkat çekici ifade; Demokrat Parti'nin seçimlere giderken değiştirdiği seçim kanunu ile: "Büyükşehirlerde oy kaybının olması muhtemel olsa bile, seçimlerdeki mevcut çoğunluk oylama sisteminin yardımıyla yeniden galip geleceği” "şeklindeki ifadeleri ve 1957 seçimleri neticesinde de gerçekleşmiş olan öngörülerine dair ifadeleridir.

\section{Sonuç}

Başlangıcından, çalışmanın yoğunlaştığı 1957 yılına kadar geçen dönem zarfındaki, TürkAlman ilişkilerinin genel seyri dikkate alındığında; iki devletin ilişkilerini izah ederken 'dost' ve 'müttefik' sıfatlarını kullanılması herhalde doğru bir yaklaşım olacaktır. Nitekim, tarih boyunca 'ortak fayda' ekseninde gerçekleşen Türk-Alman ilişkileri, II. Dünya Savaşı sonrasında da bu tarihsel seyrine uygun düzlemde devam etmiştir. Bu doğrultuda Türk-Alman ilişkileri, Federal Almanya'nın kurucu Cumhurbaşkanı Dr. Theodor Heuss'un Türkiye ziyareti sırasında vurgu yaptığ 1 'tarihi kişilikler' özelinden de değerlendirildiğinde; 'dost' ve 'müttefik' sözcükleri daha da anlam kazanmaktadır. Hal böyle iken; Almanya'nın Türkiye'deki diplomatik misyonları aracıllğıyla Türkiye'nin ahval ve şeraitine dair malumat sahibi olma yönündeki arzuları bir raddeye kadar anlaşılmakla beraber, Demokrat Parti ile muhalefet arasındaki yakınlaşmaya dair tuttukları raporlar ve seçimlere dair kapsamlı analizleri, bu raporların dünyadaki herhangi bir ülkede bulunan diplomatik misyonların genel bilgilendirme raporlarından epey farklı olduğunu adeta kanıtlar niteliktedir.

Demokrat Parti iktidarı ile birlikte Cumhuriyet'in kazanımları noktasından farklı bir hal alan Türkiye Cumhuriyeti dış politikası Bayar-Menderes ikilisinin faaliyetleri neticesinde kimi 
zaman Atatürk'ün dış politikasıyla çelişen yönleri ile de dikkat çekmektedir. Avrupa'ya uçak ihraç eden Türkiye'den, Avrupa'dan kredi talep eden ülke konumuna gelinmesinde şüphesiz evvela İnönü ve akabinde de Menderes hükümetlerinin payları vardır. Nitekim Türkiye, 'Yurtta Sulh Cihanda Sulh' ilkesi doğrultusunda belirlenen dış politika ekseninde gerçekleştirilen 'Balkan Antantı' ve 'Bağdat Paktı' gibi önemli oluşumlarla bölgesinde söz sahibi bir uluslararası aktör olarak dünyada da önemsenen ve Birleşmiş Milletler'e davetle katılan ülke konumundan, Kore'ye asker göndererek henüz üyesi dahi olmadığı NATO'ya girebilmek için çabalayan ülke durumuna getirilmiştir. Almanya ile ekonomik ilişkileri geliştirebilmek amacıyla, Cumhurbaşkanı Heuss'un ifadesiyle; Ankara yollarını Almanya'da bile görülmeyen sayıda Alman bayrakları ile donatan, başarısız dış politikası nedeniyle 6-7 Eylül olayları gibi tarihe geçecek bir kara leke yaşanmasına sebep olan, Bandung konferansındaki tutumu nedeniyle tarihsel birikimini ve prestijini hiçe sayarak konferansta adeta emperyal devletlerin sözcülüğüne soyunan ve dış politikada sıkıştıkça iç politikada yeni demagoglar yaratan ülke konumuna getirilen Türkiye Cumhuriyeti'nin, Federal Almanya karşısındaki durumu çalışmada bir kısmına değinilen dönemin gazeteleri ve elçilik raporları incelenince ortaya çıkmaktadır.

1936'dan 1938'e kadar Almanya, Türkiye'nin en fazla ithalat yaptığı ülkelerden biridir. Türkiye'nin ithalatının \%44,9'u Almanya'dan sağlanırken, Türkiye'nin Almanya'ya ihracatı ise $\% 43,1$ oranındadır. Yani Atatürk döneminde, üstelik Almanya'da Naziler iktidarda iken ve Almanlar iktisadi anlamda en güçlü dönemlerini yaşarlarken bile, Türkiye ile başa baş bir diş ticaret profili çizilmekte idi. Türk-Alman ilişkilerindeki seyrin Demokrat Parti ile birlikte nereden nereye geldiğini anlamak için Menderes'in 1954 ve 1958 yıllarında yaptığı Almanya ziyaretlerine bakmak bile kâfidir. Zira, Atatürk dönemindeki durumun aksine Almanya'dan kredi talep eden ve dış ticaretinde tarım ürünü ihracatı yaparak sanayi mallarını ithal etmeye çalışan bir ülke haline gelinmiştir. Bu kötü gidişatı salt Demokrat Parti iktidarına yüklemek haksızlık olmakla beraber, durumun bu hali almasındaki en büyük payın da Menderes hükümetlerinde olduğunu ifade etmek yerinde olacaktır.

Almanya'nın Türkiye'nin siyasal hayatına neden bu denli alakalı olduğunu kavrayabilmek için de, ülkenin nereden nereye geldiğini göz önünde bulundurmak gerekir. Zira, Almanya'dan kredi alan ülke konumunda olan Türkiye'nin risklerini ancak yakından takip ederek tespit etmelerinin mümkün olacağı kanaatinde olmaları Almanlar için tabi karşılanabilir. Ancak raporlarda dikkat çeken husus risk analizi yapmaktan öte Demokrat Parti'nin antidemokratik uygulamaları ile adeta Almanlarca fişlenmesidir.

II. Dünya Savaşı neticesinde müttefiklerce kurulan bir proje devlet olan Federal Almanya'nın, üzerindeki bütün emperyal baskılara rağmen kısa sürede kalkınarak dünya siyasetinde ve ticaretinde söz sahibi konuma gelirken yararlandığı tarihsel alt yapısından hareketle; dış politikasını belirleme noktasında diplomatlarının hazırladıkları elçilik ve konsolosluk raporlarından nasıl faydalandıklarına dair örneklere çalışma içerisinde yer verildi. Bu noktada, müteveffa A.B.D. Başkanı John F. Kennedy'nin 1960 seçim kampanyası sırasında San Francisso Cow Palace'de yaptığı seçim mitinginde belirttiği husus oldukça anlamlıdır. Zira, Kennedy A.B.D. diplomatlarının S.S.C.B. diplomatları karşısındaki yetersizliğinden yakınarak: "Büyük devlet olmak için dünyayı analiz ederek, dış politikada yol haritasını çizebilen diplomatlara sahip olmak gerektigini” vurgulamaktayd1.

Netice itibariyle, Federal Almanya Dışişleri Bakanlığı siyasi arşivinde bulunan belgeler ile gözler önüne serilen Alman diplomatik misyonlarının çalışma sistemi, halen dünya 
siyasetinde ve ekonomisinde söz sahibi olmayı hedefleyen bir ülkenin yapması gereken nitelikte olduğu söylenebilir. Bu doğrultuda, 1957 seçimlerinin akabinde, 1958 y1lı içerisinde Bayar ve Menderes'in Almanya ziyaretleri de değerlendirildiğinde, Almanların her türlü seçim sonucuna hazırlıklı olarak, Türkiye'de iktidar değişikliği olsa bile, Türk-Alman ilişkilerinin aynı düzlemde devamına yönelik bir siyaset izledikleri ifade edilebilir.

Dış politika belirleme sürecinde o dönemlerde aktif olarak kullanılan elçilik raporları sistemi esasen Türk hariciyesinin de yabancı olmadığı bir yöntemdir. Zira, III.Ahmed döneminden itibaren 'ad-hoc diplomasi' yoluyla muhatap devletlere gönderilen sefirlerin (elçilerin) tuttukları sefaretname (elçilik raporları) örneklerine Osmanlı arşivlerinde 1720 yılından itibaren rastlanmaktadır. Ancak, özellikle Atatürk sonrasında başlayan eğitim alanındaki çözülme süreci, Demokrat Parti döneminde iyice gün yüzüne çıkmış ve hemen hemen her alanda olduğu gibi hariciye alanında da nitelikli personel yetiştirilmesi noktasında, Alman diplomatların raporlarına mütekabiliyet esasına uygun şekilde eylemde bulunabilecek donanıma sahip diplomatların noksanlığını, Türk Dışişleri arşivlerinde aynı nitelikte elçilik raporlarına rastlanmaması adeta kanıtlar niteliktedir. Nitekim, çalışmada olaylarla ortaya konmuş olan Alman diplomatların raporlama sisteminin, büyük devlet olma idealinde olan bir ülkenin dış politikasında yol haritası çizilmesi hususundaki öneminin örnek olacak nitelikte olduğu ifade edilebilir. 
G. Eşel, "Federal Alman Dışişleri Arşiv Belgelerine Göre Demokrat Parti Dönemi Türk-Alman İlişkilerinde 1957 Seçim Süreci”

\section{Kaynakça}

Albayrak, M. (2004). Türk siyasi tarihinde Demokrat Parti (1946-1960). Ankara: Phoenix Yayınevi.

Adenauer ile yapılan görüşmeler sona erdi. (1954). Milliyet Gazetesi, 22 Mart 1954.

Almanya Başvekili dün Ankara’ya geldi. (1954). Milliyet Gazetesi, 19 Mart 1954.

Alman Başbakanın ziyareti. (1954). Erişim https://www.youtube.com/watch? $\mathrm{v}=\mathrm{XbHwgIJEMVU \& t=62 \textrm {s }}$

Almanya Büyükelçiliği resmi internet sitesi. Alman Büyükelçiliği. Erişim Adresi: https://tuerkei.diplo.de/tr-tr/themen/politik/0-hochrangige-besuche/1793980

Artvinli, F. (2004). Türk siyasal hayatında Osman Bölükbaşı (Yayımlanmamış doktora tezi). Yıldız Teknik Üniversitesi, Sosyal Bilimler Enstitüsü, İstanbul.

Ayhan, E. (2006). Osman Bölükbaşı'nın siyasi faaliyetleri 1913-2002 (Yayımlanmamış doktora tezi). Marmara Üniversitesi, Türkiyat Araştırmaları Enstitüsü, İstanbul.

Ayhan, İ. (2014). Demokrat Parti döneminde Türkiye 'yi ziyaret eden devlet başkanlart ve bu ziyaretlerin Türk basınına yansımaları (Yayımlanmamış doktora tezi). Dicle Üniversitesi Sosyal Bilimler Enstitüsü, Diyarbakır.

Batı Almanya Başvekili dün şehrimizden ayrıldı. (1954). Milliyet Gazetesi, 27 Mart 1954.

Boran, T. (2011). Mekân ve siyaset ilişkisi bağlamında Anıtkabir 1938-1973 (Yayımlanmamış doktora tezi). Ankara Üniversitesi, Türk İnkılâp Tarihi Enstitüsü, Ankara.

Deringil, S. (2007). Denge oyunu İkinci Dünya Savaşı’nda Türkiye’nin dış politikası. İstanbul: Tarih Vakfi Yurt Yayınları.

Dr. Heuss Bonn'a vardı. (1957). Milliyet Gazetesi, 15 Mayıs 1957.

Dr. Heuss İstanbul'da. (1957). Milliyet Gazetesi, 10 Mayıs 1957.

Eberle, H. ve Uhl, M. (2015). Hitler kitabı. İstanbul: NTV Yayınları.

Eroğul, C. (2003). Demokrat Parti tarihi ve ideolojisi. Ankara: İmge Kitabevi.

Gülmez, N. ve Demirci E. (2013), Von Papen'in Türkiye Büyükelçiliği. Çăgdaş Türkiye Tarihi Araştırmalarl, 13(27), 225-250. Erişim adresi: https://dergipark.org.tr/tr/pub/cttad/

Hawes, J. (2019). Klsa Almanya tarihi. İstanbul: Say Yayınları.

Irmak, Ö. (2009). Adnan Menderes’in yurt dışı gezileri (Yayımlanmamış doktora tezi). İstanbul Üniversitesi, Atatürk İlkeleri ve İnkılâp Tarihi Enstitüsü, İstanbul.

James, H. (2009). Alman kimliği 1770’den bugüne. İstanbul: Kızılelma Yayıncılık.

Karavar, H. (2019), Türk-Alman ticari ilişkilerinde yeniden canlanma: 1949-1954 y1lları. Mediterranean Journal of Humanities, 9(2), 373-387. doi:10.13114/MJH.2019.496

Kıvırcık, E. (2007). Büyükelçi. İstanbul: GOA Yayınları.

Köksal, A. (2004). Türk siyasi hayatında Osman Bölükbaşı (Yayımlanmamış Yüksek Lisans Tezi). Karadeniz Teknik Üniversitesi, Sosyal Bilimler Enstitüsü, Trabzon.

Krupp bugün Ankara’ya geliyor. (1957). Milliyet Gazetesi, 15 Mayıs 1957.

Langlois, G. (2003). 20. Yüzyll siyasi tarihi. İstanbul: Nehir Yayınları.

Neziroğlu, İ. ve Yılmaz, T. (2014). Başbakanlarımız ve genel kurul konuşmaları (Cilt 4). Ankara: Türkiye Büyük Millet Meclisi Başkanlığg Yayınları.

Oran, B. (2019). Türk dış politikası (Cilt 1). İstanbul: İletişim Yayınları.

Ökçün, A. G. (1974). Türk Antlaşmaları rehberi. Ankara: Ankara Üniversitesi, SBF Yayınları.

PA AA 304 81 00/2. (1 Nisan 1957). 1 Nisan 1957 tarihli elçilik raporu. Federal Dışişleri Bakanlığı Siyasi Arşivi Belgeleri (Politisches Archiv Auswärtiges Amt ) 
PA AA 304 81 00/1. (15 Temmuz 1957). 15 Temmuz 1957 tarihli elçilik raporu. Federal Dişişleri Bakanlığı Siyasi Arşivi Belgeleri (Politisches Archiv Auswärtiges Amt)

PA AA 30481 00/1. (14 Eylül 1957). 14 Eylül 1957 tarihli elçilik raporu. Federal Dışişleri Bakanlığı Siyasi Arşivi Belgeleri (Politisches Archiv Auswärtiges Amt)

PA AA 30481 00/1. (15 Ekim 1957). 15 Ekim 1957 tarihli elçilik raporu. Federal Dışişleri Bakanlığı Siyasi Arşivi Belgeleri (Politisches Archiv Auswärtiges Amt)

Sezen, S. (1994). Seçim ve demokrasi. Ankara: Gündoğan Yayınları.

Sükan, F. (1991). Başbakan Adnan Menderes ’in meclis konuşmaları. Ankara: Kültür Ofset.

Şeyhanlığlu, H. (2011). Türk siyasal muhafazakârlı̆̆ının kurumsallaşması ve Demokrat Parti. Ankara: Kadim Yayınları.

Taşdemirci, E. (1992). Belgelerle 1933 üniversite reformunda yabancı bilim adamları. Ankara: Bizim Büro Basımevi.

Türkiye Büyük Millet Meclisi. (1924). Türkiye Cumhuriyeti ile Almanya Cumhuriyeti arasında münakit 3 Mart 1340 (1924) tarihli Muhadenet muahedenamesi hakkında kanun. Erişim Adresi: https://www.tbmm.gov.tr/tutanaklar/KANUNLAR_KARARLAR/kanuntbmmc002/kanuntbmmc0 02/kanuntbmmc00200483.pdf

Türk-Alman İktisadi İşbirliği. (1957). Milliyet Gazetesi, 24 Mart 1957.

Türk-Alman Görüşmeleri. (1957). Milliyet, 7 Mayıs 1957.

Yurtoğlu, N. (2014). Demokrat Parti Dönemi tarım politikalarl ve siyasi, sosyal, ekonomik hayata tesirleri 1950-1960 (Yayımlanmamış doktora tezi). Hacettepe Üniversitesi, Atatürk İlkeleri ve İnk1lâp Tarihi Enstitüsü, Ankara.

Yücel, S. M. (2001). Demokrat Parti. İstanbul: Ülke Kitapları. 
G. Eşel, "Federal Alman Dişş̧̧leri Arşiv Belgelerine Göre Demokrat Parti Dönemi Türk-Alman İlişkilerinde 1957 Seçim Süreci”

\section{Ekler}

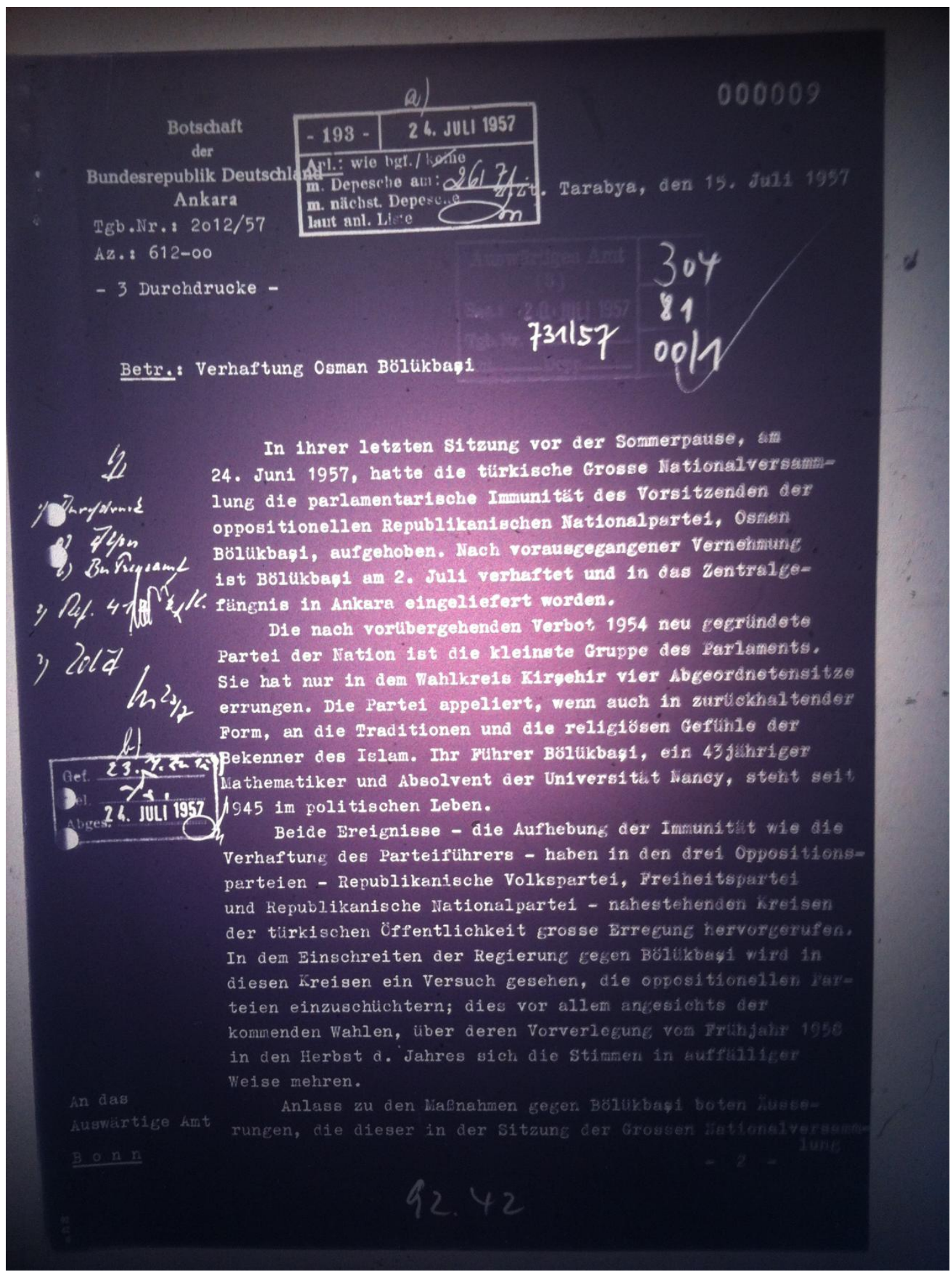


Ekonomi, Politika \& Finans Araştırmaları Dergisi, 2020, 5(3): 868-892

Journal of Research in Economics, Politics \& Finance, 2020, 5(3): 868-892

vom 12. Juni 1957 getan haben soll. In dieser Sitzung war das Gesetz diskutiert worcen, das der stadt Kirsehir (südöstlich von Ankara) den Charakter einer Vilayetshauptstadt vieder zurück-gibt, der inr aut Initiative der ReGierung nach de* Wahl von 1954 offensichtlich als "Strafe" für die oppositionelle Stimmabgabe der dortigen Bevölkerung genommen worden war.

Bölukbagf soll in der sitzung vom 12. Juni vom Rednerpult des larlaments herab den Abgeordneten wegen ihrer Haltung in dieser lrage schwere persönliche Anschuldigungen zugerufen und sethe fusservngen später auf dem Gang der Nationelversamiung viederholt haben. Hierin will die Regierung ein Vergehen im Sinne des $\$ 159$ des tükischen Strafgesetrbuchs sehen. Dieser Paragraph sieht eine Gefingrisstrafe von 1 - 6 Jahren für denjenigen vor, der sich einer öfentlichen Beleidigung der Grossen Nationalversamilung schuldie macht.

Nach vorangegangenem Zusamentritt einor Parlamentskornission und nach einer ausserordentich stïrmischen Debatte, aus der besonders aie Intervention Inönis zugunster Bölübagis hervorzuheben ist, vurde die Immunität des Abgeorineten von Kirpehir mit 247 fegen 49 Stimen - etwa 100 Abeeordnete haben sich nicht en der Mbstimmune beteiligt - aufgehoben. Dies bot die rechtiche Mölichkeit zu seiner eine Foche speiter erfolgten Vorhaftune. Die Opposition behauptet wohl nicht mit Unrecht, dab es sich bei diesem Vorgehen ur eine persönliche Initiative ces Inisterprisidenten Adnan Mienderes handelt.

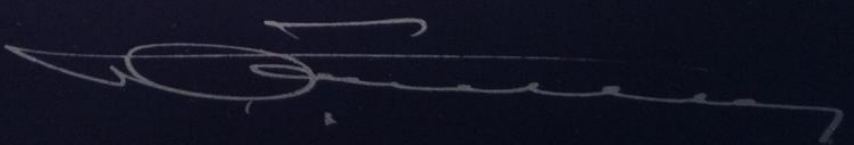




\title{
1957 ELECTIONS PROCESS IN TURKISH-GERMAN RELATIONS DURING DEMOCRATIC PARTY ERA ACCORDING TO THE GERMAN FEDERAL FOREIGN OFFICE ARCHIVE DOCUMENTS
}

\author{
EXTENDED SUMMARY
}

\begin{abstract}
Aim of the Study
The aim of this study is to explain Turkish-German Relations from beginning to the Democratic Party Era and especially in the Democratic Party Era between 1957 elections process above the embassy and the consular reports of the Ministry of Foreign Affairs of the Federal Republic of Germany and especially the correspondence between their diplomatic missions in Turkey.
\end{abstract}

\section{Relevant Literature}

The documents contained in the Federal German Foreign Office Policy archive are the main sources of this study. There are four folders in the archive that includes the reports written by the diplomatic missions of the Federal German Republic in Turkey. There are classified as: (PA AA 304 81 00/2: 1 April 1957, PA AA 304 81 00/1: 15 July 1957, PA AA 304 81 00/1: 14 September 1957 and PA AA 30481 00/1: 15 October 1957). Its is easily understood that Turkey's domestic politics closely involved with the content of the reports received from the diplomatic missions of Germany. There aren't many studies in the literature especially about this point but there are a few studies that includes some information on the 1957 elections. Artvinli (2004), Ayhan (2006) and Köksal (2004) gave some information about the arrestment of the opposition party leader Mr. Osman Bölükbaşı in their master thesis. And also there are some information in the literature about the 1957 electoral law. Sezen (1994) stated that the 1957 elections were unequal for the opposition because of the new electoral law. James (2009), Hawes (2019), Eberle and Uhl (2015) and Karavar (2019) studied German foreign politics. Albayrak (2004) also an important source about the Democratic Party Era.

\section{Methodology}

In the study, the case study method, which is frequently used in the literature, is utilized for historical case analysis above the archive documents. Turkish-German relations dealt with over an event have been tried to be viewed from a broad perspective. On the other hand, in this study, by the transcription of the embassy reports, a methodology based on historical evidence was applied.

\section{Results and Conclusion}

According to the study, Turkish-German relations have been on the axis of trade and military alliance from the beginning and from the perspective of both states, great emphasis has been placed on strengthening and developing relations. Thus, in the period of Democratic Party 
Government that important events took place in Turkish Foreign Policy, beginning of the development of relations with the West has brought Turkey's NATO membership. In this process, Germany, which is divided into East and West after the Second World War, the relations between Turkey and the west side of the Germany has been seen after Turkey's NATO membership. Under the umbrella of NATO, against S.S.C.B. and among other countries including the German Democratic Republic named the East part of the Germany, Federal Republic of Germany named the West part of the Germany was allied with the Republic of Turkey. By the way there were lots of important cases appeared. Germany's interest above the Turkey's internal politics is understandable at this point. But the striking point here is that the Germans predictions about the 1957 elections were mostly correct. 